\title{
1835/1836 Tarihli Nüfus Defterine Göre Hısnımansur Kazası Nüfus Yapısı ve Gayrimüslim Nüfusun Şehrin Ekonomik Yapısındaki Yeri
}

\author{
Hesnimansur Town, Its population and the Place of Non-Muslims in its \\ Economy from the Population Register of 1835/1836
}

\begin{abstract}
Seydi Vakkas TOPRAK ${ }^{*}$
Öz: Osmanlı Devleti, Yeniçeri Ocağını kaldırdıktan sonra yeni kurduğu modern ordunun ihtiyaç duyduğu insan ve finansman kaynaklarını tespit etmek amacıyla 1831'den itibaren nüfus sayımları yapmıştır. Ülke genelinde yapılmaya çalışılan bu sayımlar imparatorluğun farklı bölgelerinde farklı zamanlarda uygulanabilmiştir. Modern anlamda ilk modern nüfus sayımı, başkentten uzak küçük bir kaza olan Hısnımansur'da ancak 1835 yılında yapılabilmiştir. Bu çalışma bahsi geçen sayımın verilerine göre şehirde yaşayan gayrimüslim cemaatin demografik durumunu tespit etmeyi hedeflemektedir. Bu çalışmada şehrin genel nüfusu, yaklaşık nüfusun beşte birlik kısmını oluşturan gayrimüslim cemaatinin nüfus yapısı, şehirdeki iş ve meslek kolları, gayrimüslimlerin uğraştığı meslekler ile gayrimüslim cemaatin şehrin ekonomik faaliyetleri içerisindeki konumu incelenmiştir.
\end{abstract}

Anahtar sözcükler: İlk Nüfus Sayımı, Hısnımansur Nüfusu, Gayrimüslim Nüfus, Meslekler, Sanatlar

Abstract: Following the abolition of the Janissaries the Ottoman State began to conduct censuses from 1831 onwards to determine the human and financial sources that were available for the newly constituted modern army. The attempt was made to conduct these censuses throughout the entire territory but they could only be conducted in different regions of the state on different dates. Only during the latter part of 1835 was the first modern census conducted in Hisnımansur, a small town far from the capital. The aim of this study was to determine the demographic situation of the non-Muslim community of Hisnimansur from the data recorded in the population register of $1835 / 1836$. This paper examines the total population, the non-Muslim population consisting of one in five of the approximate total population, the jobs and branches of professions, which professions the non-Muslims practiced and the position of the nonMuslim community within the economic activities of the inhabitants of Hisnımansur.

Keywords: The First Census, The population of Hisnımansur, Non-Muslim Population, Professions, Crafts

\section{Giriş}

Osmanlıların 19. yüzyıldan itibaren arazi kaydı, vergi tespiti ve askere alma dolaysıyla insanları da kayıt altına aldığı bilinmektedir. Fethedilen yerler hemen tahrire tabi tutulurdu. Ayrıca olağanüstü durumlarda tahrir yapıldığı gibi otuz yılda bir tahrirler yenilenirdi. 17. yüzyılda terkedilen tahrir kayıtları yerini avarız kayıtlarına bırakmış, tahrirler 19. yüzyılda temettuat kayıtları şeklinde devam etmiştir. Doğrudan nüfus tespiti amacıyla tutulmamış olan bu kayıtlar demografi alanında çalışanlar için önemli kaynak niteliğindedir (Çimen 2012, 189-190). 19. yüzyılın ilk yarısında ise askerî ve malî açıdan nüfusun sayılması bir zorunluluk haline gelmiş-

\footnotetext{
*Yrd. Doç. Dr., Adıyaman Üniversitesi, Fen Edebiyat Fakültesi, Tarih Bölümü, Adıyaman. seyditoprak@gmail.com
} 
tir. Yeniçeri Ocağının lağvından sonra kurulan Asakir-i Mansure için gerekli para ve insan kaynağını saptamak için nüfus sayımı yapmak gerekmiştir. Vaka-i Hayriyeden hemen sonra nüfus sayımı için girişimler olduysa da Yunan isyanı ve Rusya ile olan savaş dolayısıyla neticeye varılamadı. Osmanlı tarihindeki ilk modern nüfus sayımına ancak 1931 yılında başlanabildi. Bu sayım Anadolu, Rumeli ve Akdeniz adalarında gerçekleştirildi (Karal 1997, 13-17; Ahmed Lütfi Efendi 1999, 640). Araştırmacılar 1831'de uygulamaya konulan nüfus kayıt işleminin asker kaynağının tespiti, vergilerin dağılımı ve tahsilinde görülen aksaklıkların bertaraf edilmesi ve cizyenin yeni şartlara göre belirlenmesi amacıyla yapıldığı hususunda hem fikirdirler (Çimen 2012, 194-195).

Şüphesiz ki asker kaynağını Müslüman halk oluşturmaktaydı. Vergi ise tüm halktan alınmaktaydı. Dolayısıyla II. Mahmud döneminde yapılan nüfus sayımlarında hem Müslümanların hem de gayrimüslimlerin kayıt altına alınmasına gayret edilmiştir. Ancak ülkede yaşayan tüm insanlar kaydedilmemiş, sadece vergi verme ve askere gitme potansiyeline sahip insanlar nüfus defterine kaydedilmiştir. Genel olarak erkekler yoklamaya tabi tutulmuş, kadınlar kayıt altına alınmamıştır (Çadırc1 2013, 45). Bu yönüyle 1831'de uygulanan nüfus sayımı gerçek nüfus sayısını ortaya çıkarmaktan uzaktır. Yine bu sayımla ülkenin her yeri yoklanmadığı için de 1831 sayımı ile reel nüfusu tespit etmek mümkün olmamıştır.

Ülke genelinde yapılan nüfus sayım sonuçlarının bir araya getirilerek değerlendirilmesi ve belirtilen tarihten itibaren nüfus işlerini düzenlemesi için merkezde Ceride Nezareti (Ceride-i Nüfus Nezareti) teşkil edilmiştir. Eyalet ve sancaklarda ise nüfus işleriyle görevli Defter Nazırlıkları kurulmuştur. Tanzimatttan itibaren nüfus ile ilgili kurumlar geliştirilmiş, eyaletlerde nüfus nazırları, sancak ve kazalarda ise nüfus memurları görevlendirilmiştir (Çimen 2012, 199; Çadırc1 2013, 45; Demirci \& Kartal 2014, 121).

1831 ve sonrasında yapılan Osmanlı nüfus sayımlarının gerçek nüfusu saptayamamasının bir başka nedeni de tüm nüfusun kaydedilememesidir. Nüfus sayımı sırasında; nüfus miktarına göre devletin her bölgeye yeni sorumluluklar yükleyeceği şayiası yayılınca, taşradaki halk kayıt altına alınmaktan kaçınmıştır. Çoğu yerde nüfus olduğundan az gösteriliyor, gayrimüslimler hükümete karşı sorumlu liderlerini bu hususta aldatıyor ve her yerde nüfus gizleniyordu. Nüfus memurları gerekli titizliği göstermediğinden önemli miktarda nüfus kayda geçirilemiyordu (Karal 1997, 9). Yine göçebe gruplar, yolların olmayışı, coğrafi ve mevsimsel şartlardan dolayı bazı yerler yoklamaya dâhil edilememiştir.

İlk nüfus sayımının 1831 yılında ülkenin her yerinde yapılamadığı yukarıda belirtilmişti. Nüfus sayımının uygulanmadığı yerlerden biri de Hısnımansur kazasıdır. Hısnımansur'un ismi 1831 'de nüfus sayımı yapılan yerler arasında geçmemektedir. Osmanlı Arşivindeki nüfus defterleri arasında tespit ettiğimiz Hısnımansur'a ait en eski tarihli nüfus defteri hicri 1251 tarihlidir. Bu defterin verilerine göre adı geçen kazada ilk nüfus sayımı 29 Nisan 1835 ile 17 Nisan 1836 tarihleri arasında yapılmıştır. Bu çalı̧̧mada Hısnımansur'da yapılan ilk nüfus sayımı için 1835 yılı başlangıç olarak kabul edilmiştir.

Temel kaynak olarak kabul ettiğimiz nüfus defteri, Hısnımansur kazasının hem Müslüman hem de gayrimüslim halkını kayıt altına almıştır. Bu çalışmada, sadece erkeklerin yazıldığı $\mathrm{h}$. 1251 tarihli Hısnımansur nüfus defterinin verileri esas alınarak 1835 yılında Adıyaman'da yaşayan gayrimüslim nüfusun demografik durumu tespit edilmiştir.

\section{H. 1251 (1835/1836) Tarihli Hısnımansur Kazası Nüfus Defteri}

İncelediğimiz Hısnımansur Nüfus Defteri Başbakanlık Osmanlı Arşivi’nde (BOA) nüfus defterleri kataloğunda NFS.d. 2699 sıra numarası ile kayıtlıdır. Defter, kapak dâhil 58 varaktan ibaret- 
tir. Defterin varak sayıları Arap harfleriyle alfabetik sırayla verilmiş olmasına rağmen bazı varaklar numarasızdır. Tasnif sirasında uzmanlar deftere Arap rakamları ile yeniden numara vermişlerdir. Yeni tasnife göre 116 sayfadan ibaret olan defterin 1, 84-86, 99-100, 110-116 numaralı sayfaları boştur. $18 \times 46 \mathrm{~cm}$ ebadında olan defterin tanzim tarihi kapaktan sonraki ilk sayfada h. 1251 olarak yazılı olup ay ve gün belirtilmemiştir. Arşiv kataloğunda ise 29 Zilkade 1251 tarihi kayıtlıdır. İyi korunmuş olan defter okunaklı bir çeşit rika yazısı ile yazılmıştır. Defterde iki farklı kaligrafi kullanılmıştır.

Defterdeki bilgiler belli bir düzen içerisinde tanzim edilmiştir. Mahalleler, nahiye ve köyler ile göçebeler başlıklar altında kaydedilmiştir. Hane bilgisiyle birlikte şahısların isimleri, baba isimleri ve yaşları yazılmıştır. Şahısların çoğunun lakapları ve meslekleri de belirtilmiştir. Ayrıca herhangi bir bedensel özrü olanlar için de ismin üst kısmına yek çeşm, âmâ sağır ve mecnun gibi ifadelerle not düşülmüş̧ür.

Hısnımansur'da nüfus sayımı yapmakla görevli ve defteri tanzim eden memurun ismi, defterde açıkça zikredilmese de, defterin iki yerindeki tasdik mühründen tespit edilmiştir. Bu kayda göre, adı geçen kazada h.1251 yılında nüfus sayımı yapmakla görevlendirilen kişi Hısnımansur Kadı Naibi Es-Seyyid Abdülgani Şâkir Efendi'dir (BOA, NFS.d. 2699, 98, 109). İlk nüfus sayımı kapsamında Anadolu ve Rumeli'deki Müslüman ve gayrimüslim nüfus sayılırken halkın tepkisinden korkulmuştur. Çünkü daha önce böyle topyekûn bir sayım yapılmamıştı. Ahalinin endişelerini ortadan kaldırmak isteyen hükümet nüfus sayımı için ulemadan ve nüfuz sahibi kişilerden memurlar görevlendirmiştir (Karal 1997, 12). Bu memurlar genellikle hacegândan, kadı ve naiplerden seçilmiştir (Ahmed Lûtfî Efendi 640-642). Hısnımansur nüfusunu kaydetme görevi İlmiye sınıfından bir naibe verilmiştir. Ancak defterin bizzat naip tarafından değil de, iki memur tarafından kaleme alındığı anlaşılmıştır. Çünkü defterde naibin hattından başka iki farklı kaligrafi daha kullanılmıştır. Yine naibin sadece nüfus kaydı için kazaya geldiği, naibin kaza nüfusuna kayıtlı olmamasından da anlaşılmıştır. Nüfus sayımı bittikten sonra kayıtları temize çeken naip, kadı ve naiplerin bir belgeyi imzalarken kullandıkları forma uygun olarak, defteri "Ta'allaka nazarî Es-Seyyid Abdulgânî Şâkir el-müvellâ bi-kazâ-yı Hısnımansûr" ibaresiyle imza ve mührüyle tasdik (Kütükoğlu 2013, 351) etmiş ve vazifesini tamamlamıştır.

\section{Hısnımansur'da Nüfus Sayımı ve Kazanın Nüfusu}

Tablo 1. Hısnımansur Kaza Merkezi Hane ve Nüfus Cetveli

\begin{tabular}{|c|c|c|c|c|c|c|c|}
\hline \multirow[t]{2}{*}{ Mahalle } & \multicolumn{3}{|c|}{ Müslim } & & \multicolumn{3}{|c|}{ Gayrimüslim } \\
\hline & Hane & $\begin{array}{l}\text { Erkek } \\
\text { Nüfus }\end{array}$ & $\begin{array}{l}\text { Tahmini } \\
\text { Nüfus }\end{array}$ & & Hane & $\begin{array}{l}\text { Erkek } \\
\text { Nüfus }\end{array}$ & $\begin{array}{l}\text { Tahmini } \\
\text { Nüfus }\end{array}$ \\
\hline Camii Kebir & 155 & 367 & 853 & Zımmî & 182 & 624 & 1.000 \\
\hline Çarşı Camii & 161 & 329 & 885 & Nasranlı & 20 & 76 & 110 \\
\hline Kap Camii & 173 & 382 & 952 & & & & \\
\hline Yenipınar & 149 & 329 & 819 & & & & \\
\hline Eskisaray & 134 & 324 & 737 & & & & \\
\hline Toplam & 772 & 1.731 & 4.246 & & 202 & 700 & 1.110 \\
\hline \multicolumn{5}{|c|}{ Düzeltilmiş Tahmini Nüfus Toplamı } & & \multicolumn{2}{|c|}{5.356} \\
\hline
\end{tabular}


1835/h.1251 nüfus sayım işlemi sırasında Hısnımansur Kazası çeşitli birimlere taksim edilerek sayımı yapılmış ve kayıtlar deftere geçirilmiştir. Nüfusun deftere kaydedilmesine kaza merkezinden başlanmıştır. Şehir beş Müslüman mahalleye ayrılarak kaydedilmiştir. Defterin son kısmında kaydedilen gayrimüslim haneleriyle birlikte şehir yedi yerleşim birimi olarak sayıma tabi tutulmuştur. Hısnımansur kaza merkezi kayıt altına alındıktan sonra kazaya bağlı nahiye ve köyler, yerleşik ve göçer aşiret ile oymaklar sayılmış ve deftere kaydedilmiştir. Müslüman ahalinin sayım ve kayıt işlemi tamamlandıktan sonra naip Es-Seyyid Abdülgani Şakir Efendi kayıtları tasdik ederek mühürlemiştir.

Defterin son kısmı gayrimüslim nüfusun kaydına tahsis edilmiştir. Kaza merkezinde oturan gayrimüslimler Zımmîyân Hâneleri ve Nasrânlı Hâneleri başlıkları altında iki farklı grup olarak kayıt altına alınmışlardır. İsim listelerinden anlaşıldığ 1 üzere Zımmîyân olarak tabir edilen kesimin Ermeni Hıristiyanlar, Nasrânlı olarak nitelendirilen grubun da Süryani Hristiyanlar olduğu kanaatindeyiz (Taştemir 1999, 59-60; BOA, TT, 266, 14; Kenanoğlu 2004, 39; Taşkın 2011, 121; 2013, 649; Ürek 15.03.2016).

Kaza merkezinin ardından Zırafkânlı ve İzollu köyleriyle Kâhta'da ikamet eden gayrimüslim nüfus Zımmîyân olarak deftere kaydedilmiştir. Kanaatimizce bu gruptakiler de Ermeni Hıristiyan reayadır. Gayrimüslim nüfusun kaydıyla sayım tamamlanmış ve kaza naibi defterin sonuna imza ve mührünü koyarak işlemi tasdik etmiştir.

$\mathrm{Bu}$ çalışmanın amacı kazada yaşayan gayrimüslim nüfusun demografisi olmakla birlikte, öncelikle kaza merkezinin nüfusu, ardından kazanın tüm erkek nüfusu tablolar halinde çıkarılarak gayrimüslim nüfusun konumu izah edilmiştir. Ayrıca tablolarda düzeltilmiş tahminî nüfus miktarları verilmiştir.

Düzeltilmiş tahminî nüfus hane sayısının beş katı esas alınarak hesaplanmıştır. Bu şekilde elde edilen sayıya, yine hane sayısının beş katının yüzde onu da kayıt dışı nüfüsa karşılılk gelmek üzere eklenmiştir. Ancak Osmanlı nüfusu konusunda çalışan bilim insanlarının nüfus tahmini yapmak için kullandığı bu yöntemin bilimsel bir geçerliliği olmadığını da belirtmek durumundayız. Fakat başka bir yöntem de mevcut değildir.

Ömer Lütfi Barkan, şehir nüfusunu tespit edebilmek için her haneyi beş kişiden ibaret kabul etmiştir (Barkan 1953, 12, 21). Yine kayda geçmemiş olan kesimlerin ve kölelerin de nüfusa dâhil edilmesi gerektiğini belirtmiştir. Nüfus tahminlerinde, İtalyan şehirlerindeki nüfusun yüzde 5'i ile 10'una karşılık gelen köle sayısının toplam nüfusa dâhil edilişini örnek olarak göstermiştir (Barkan 1953, 13). Osmanlı nüfusu üzerinde çalışma yapan Kemal Karpat da Osmanlı nüfus defterlerindeki rakamların nüfusun yüzde 17-22 dolaylarında eksik gösterildiğini belirtmiştir (Karpat 2010, 8).

Biz de Hısnımansur kazası nüfusunu saptarken her hanenin beş nüfustan ibaret olduğunu kabul ettik. Kayıt dışı nüfusa karşılık gelmek üzere de elde edilen sayının yüzde 10'unu toplam nüfusa ekledik. Defterde kayıtlı olup da hanesi yazılmamış olan nüfusu da bu yüzde onluk kısma dâhil ettik. Buna göre Hısnımansur kazası merkezinde yaşayan 5.356 kişiden 4.246'i Müslüman, 1.110'u da gayrimüslimdir. Gayrimüslimlerden Zımmî olarak kayıtl1 1.000 civarındaki grubun Ermeni, Nasrânlı olarak yazılan 110 civarındaki grubun da Süryani olduğu kanaatindeyiz. Kazaya bağlı bir köy, on aşiret ve oymak ile 165 köyde yaşayan yaklaşık 15.793 kişiden sadece 128 'i gayrimüslim, geriye kalan kahir ekseriyet ise Müslümand1. Nüfusu yaklaşık 21.329 kişi civarında olan Hısnımansur'da takriben 1.238 gayrimüslim yaşamaktaydı. 
Tablo 2. Hisnımansur Kazası Hane ve Nüfus Cetveli

\begin{tabular}{|c|c|c|c|c|c|c|}
\hline \multirow[b]{2}{*}{ Yerleşim Yerleri } & \multicolumn{3}{|c|}{ Müslim } & \multicolumn{3}{|c|}{ Gayrimüslim } \\
\hline & Hane & $\begin{array}{l}\text { Erkek } \\
\text { nüfus }\end{array}$ & $\begin{array}{l}\text { Tahmini } \\
\text { nüfus }\end{array}$ & Hane & $\begin{array}{l}\text { Erkek } \\
\text { Nüfus }\end{array}$ & $\begin{array}{l}\text { Tahmini } \\
\text { nüfus }\end{array}$ \\
\hline Hisnımansur Merkez & 772 & 1.731 & 4.246 & 202 & 700 & 1.110 \\
\hline Hısnımansur Ova Köyleri: 38 Köy & 434 & 940 & 2.387 & & & \\
\hline Hıdırsor Aşireti: 8 Köy, Göçerler & 307 & 900 & 1.688 & & & \\
\hline Turuş ve Havâss Köyleri: 18 Köy & 188 & 465 & 1034 & & & \\
\hline Rumyân Aşireti & 106 & 199 & 583 & & & \\
\hline Taşil Nahiyesi: 4 Oymak, 31 Köy & 215 & 453 & 1183 & & & \\
\hline Kalyon Kâvisi Aşireti: 18 Köy & 153 & 326 & 842 & & & \\
\hline Zırafkân Aşireti: 33 Köy & 415 & 776 & 2.282 & 11 & 24 & 61 \\
\hline Kömür Kâvisi: 13 Köy & 339 & 678 & 1865 & & & \\
\hline Paşa Kâvisi: 9 köy & 158 & 305 & 869 & & & \\
\hline İzol Aşireti: 4 Köy & 104 & 210 & 572 & 5 & 7 & 28 \\
\hline Kâhta & 100 & 163 & 550 & 7 & 18 & 39 \\
\hline Kâhta-Köyler: 10 Köy & 253 & 437 & 1.294 & & & \\
\hline $\begin{array}{l}\text { Kürdli Aşireti: Koçali Köyü, İbrahim } \\
\text { Ağa Oymağı }\end{array}$ & 65 & 109 & 358 & & & \\
\hline Molikânlı Aşireti: Tejinkânlı Oymağı & 44 & 73 & 242 & & & \\
\hline Toplam & 3.653 & 7.765 & 19.995 & 225 & 749 & 1.238 \\
\hline 1 Nahiye, 10 Aşiret ve Oymak, 165 Kö & & & Toplam I & ne: 387 & & \\
\hline Toplam Erkek Nüfus: 8.514 & & & Tahmini & oplam I & fus: 21 & \\
\hline
\end{tabular}

\section{Hısnımansur'da Gayrimüslim Nüfus}

Hısnımansur'da, 1835'te yapılan nüfus sayımında ahali Osmanlı millet sistemine uygun bir şekilde Müslüman ve gayrimüslim olarak tasnif edilmiştir. Defterde ahalinin etnik kökenine işaret edecek herhangi bir ibare mevcut değildir. Şehir merkezinde yaşayan gayrimüslimler Zımmî ve Nasrânlı olmak üzere iki farklı kategoride değerlendirilmiştir. Kırsal kesimde yaşayan gayrimüslimler ise Zımmî olarak deftere yazılmıştır. Zımmîlerin Ermeni, Nasrânlıların ise Süryani oldukları yukarıda belirtilmişti.

İncelediğimiz nüfus defterinin kayıtlarına göre 1835 yılında Adıyaman şehrinde 1.000 civarında Ermeni ve 110 civarında Süryani yaşamaktaydı. Nahiye ve köylerde ise 128 civarında Ermeni yaşamaktaydı. Şehir merkezinde kayıt altına alınan 202 gayrimüslim hanesinin tahmini nüfusu 1.110 kişi civarındaydı. Buna göre 5.356 nüfuslu Hısnımansur kaza merkezinde gayrimüslimler yaklaşık olarak nüfusun beşte birini (\% 20) teşkil etmekteydiler. Kısal kesimde kayıt altına alınan 23 gayrimüslim hanesinden 49 kişi nüfus defterine yazılmıştır. Bu verilere göre kırsalda yaşayan gayrimüslim nüfus tahminen 128 kişi civarında olmalıdır. Tahmini olarak 21.329 kişinin yaşadığı Hısnımansur kaza ve köylerinde nüfusunun yüzde altısını gayrimüslimler oluşturmaktaydi. 


\section{Yüzyılın İlk Yarısında Hısnımansur'da İş Hayatı Ve Gayrimüslim Cemaati}

İncelediğimiz 1835 tarihli Hısnımansur nüfus defteri, kazada yaşayanların ne tür işlerle uğraşarak geçimlerini temin ettiğini tespit etmemize imkân sağlamaktadır. Defter şehirde icra edilen iş, meslek ve sanat ve zanaat kollarını tespit etmeye yarayacak zengin veriler ihtiva etmektedir. Defterin ihtiva ettiği veriler hem Müslüman, hem de gayrimüslim nüfusun ekonomik durumunu tespit etmeye imkân sağlamıştır.

Kaza merkezi nüfusunun yaklaşık olarak beşte birini oluşturan gayrimüslimler, kazanın ekonomik faaliyetlerinin önemli bir kısmında varlık göstermekteydiler. Nüfus defterinin kayıtlarına geçen verilere göre; kaza merkezinde faaliyet gösteren 772 iş ve zanaat erbabından 554'ü Müslümanlardan oluşurken 218'i gayrimüslimlerdendi. Müslümanlar daha çok bedensel güç ve kuvvet gerektiren, nispeten az gelir getiren çiftçilik, rençberlik, çulhacılık, terzilik, köşkerlik ve dericilik gibi işlerle uğraşırken, gayrimüslimler yetenek gerektiren ve daha çok gelir getiren kuyumculuk, kalaycılık, boyacılık, basmacılık, demircilik, kazanc1lık, kılıççılık ve tüfekçilik gibi sanatlarla uğraşmaktaydı. Her iki kesimden çerçi, çulcu, çulha, demirci, tütüncü, hallaç, kalaycı, kasap, keçeci, köşker, nalbant, marangoz, rençper, taşçı, terzi ve tüccar olarak faaliyet gösteren insanlar mevcuttu. Her iki toplumda hallaç, kasap, keçeci, köşker, neccar ve taşçı olarak geçimlerini sağlayanların sayısı birbirine yakındı. Çulha, tütüncü, hallaç ve terzilerin çoğu Müslümanlardan iken çerçi, çulcu, kalaycı, nalbant ve tüccarların çoğu gayrimüslimdi. Bazı meslekleri ise ya sadece Müslümanlar ya da gayrimüslimler icra etmekteydi. Mesleklerin tümü aşağıda tablo ile gösterilmiştir.

Aşağıdaki tablodan da anlaşılacağı gibi gayrimüslimler çiftçilik, çobanlık, bakkallık, berberlik, rençberlik, tabaklık, tellaklık, oturakçılık, serraçlık, kahvecilik, katırcılık, merkepçilik ve hamamcılık gibi zor ve meşakkatli işlere itibar etmemişlerdir. Tabloda görüldüğü gibi az gelir getiren ağır işlerin çoğuyla gayrimüslimler hiç uğraşmamışlardır. Bazılarıyla uğraşanlarda çok azdır. Örneğin şehirde bulunan 207 rençperden ve 28 terziden sadece 2'si gayrimüslimdi. Buna karşıllk hüner ve yetenek gerektiren, nispeten iyi gelir getiren demircilik, kalaycılık, nalbantlık ve tüccarlıkla geçimlerini sağlayanların çoğu gayrimüslimlerdendi. Bazı meslekler ise sadece gayrimüslimler tarafindan icra edilmekteydi. Basmacılık, boyacılık, elvanc1lık, camcılık, çilingirlik, değirmencilik, hekimlik, kazancılık, kılıççılık, kuyumculuk, tüfekçilik, kürkçülük, lülecilik, tarakçılık ve nalçacılık işleri sadece gayrimüslim ahalinin icra ettiği mesleklerdendi.

1835 Hisnımansur nüfus defterine göre maharet gerektiren meslekler arasında gayrimüslimlerin uğraştığı işlerin başında çulhacılık gelmekteydi. Şehirdeki 121 çulha esnafından 42'si gayrimüslim cemaattendi. Çulhalar, dokumacılık mesleğini icra eden kişilerdir. Cullâh (Ünal 2011, 176), culâhe, câme-bâf, nessâc, bâfende ve hülle-bâf da denilen çulha esnafı iplikten çeşitli kumaşlar dokur ve bu kumaşlardan çeşitli elbiseler dikerdi (Toprak 2015, 85). Yine dokumacılıkla ilgili olarak Hısnımansur' da yapılan mesleklerden biri de kumaş, bez ve elbise boyacılığıdı.

Boyacılık mesleğini yapanlara sabbâğ da denilirdi. Sabbă̆ kelimesi sözlükte, nesne boyac1lığı (Hüseyin Remzi 1306, 3); Develioğlu 2009, 904) için kullanıldığı gibi yalancı anlamında da kullanılmıştır. Bir kavram veya ifadeyi yanlış bir anlama, renge ve şekle çeviren kimse için de sabbâğ denilmiştir (Redhosuse 1999, 967). Hakikaten İslam'ın ilk devresinde boyacıların yalanc1 kabul edildikleriyle ilgili rivayetler mevcuttur. Hatta Hz. Peygamber'e atfedilen "Insanların en yalancıları boyacılar ve mücevher yapıcılarıdı" ş̧eklinde meşhur bir sözün varlığ bilinmektedir (Merçil 2000, 28). Bu nedenle Müslümanlar rağbet etmediğinden boyacılık mesleğini çoğunlukla gayrimüslimler icra etmişlerdir. Elimizdeki nüfus defterinin verilerine göre 1835 'te Hısnımansur gayrimüslimlerinden 4 kişi boyacılık yapmaktaydı. Oysa yaklaşık on yıl sonrasına 
ait bir arşiv kaynağına göre Adıyaman'ın yakınında bulunan Besni'de 20 boyacı esnafı bulunmaktaydı (BOA, NFS.d., 2697; Toprak 2015, 85-86). Dokumacı esnafının oldukça fazla olduğu Besni'de dokumacıların ihtiyaç duyduğu yeterli miktarda boyacı esnafının bulunması doğaldı. Hatta Besni ile Hısnımansur arasında boya ticareti yapıldığı ihtimal dâhilindedir.

Tablo 4. Hisnımansur'da İcra Edilen Meslekler

\begin{tabular}{|c|c|c|c|c|c|c|c|}
\hline \multicolumn{4}{|c|}{ Müslim } & \multicolumn{4}{|c|}{ Gayrimüslim } \\
\hline Çerçi & 1 & Çubukçu & 1 & Çerçi & 5 & Ekmekçi & 2 \\
\hline Çulcu & 2 & Dellal & 2 & Çulcu & 4 & Elvanc1 & 3 \\
\hline Çulha & 79 & Dükkâncı & 3 & Çulha & 42 & Hamal & 1 \\
\hline Demirci & 1 & Gedâ-Sail & 10 & Demirci & 6 & Hekim & 1 \\
\hline Duhanc1 & 3 & Hamamcı & 1 & Duhancı & 1 & Kazanc1 & 7 \\
\hline Hallâc & 6 & Kahveci & 10 & Hallâc & 4 & Kılıççı & 4 \\
\hline Kalaycı & 2 & Katırcı & 4 & Kalaycı & 7 & Kuyumcu & 16 \\
\hline Kasab & 1 & Kazzaz & 1 & Kasab & 1 & Külhancı & 2 \\
\hline Keçeci & 3 & Kebapçı & 1 & Keçeci & 2 & Kürkçü & 1 \\
\hline Köşker/Dikici & 32 & Leblebici & 2 & Köşker & 34 & Lüleci & 2 \\
\hline Nalbant & 2 & Merkepçi & 3 & Nalbant & 7 & Mahsaracı & 1 \\
\hline Neccâr & 2 & Mumcu & 1 & Neccâr & 3 & Makramacı & 1 \\
\hline Rencber & 205 & Odabaşı & 1 & Rencber & 2 & Nalçacı & 1 \\
\hline Taşçı & 1 & Oturakç1 & 19 & Taşçı & 2 & Ölçekçi & 2 \\
\hline Terzi & 26 & Serrâc & 8 & Terzi & 2 & Papuccu & 2 \\
\hline Tüccar & 3 & Sofac1 & 1 & Tüccar & 8 & Tahmisci & 1 \\
\hline Abac1 & 2 & Sokucu & 4 & Basmacı & 4 & Tarakçı & 3 \\
\hline Bakkal & 6 & Tabak & 17 & Bostanc1 & 2 & Tüfekçi & 5 \\
\hline Berber & 11 & Tellak & 1 & Boyacı & 4 & Zeyilci & 2 \\
\hline Bostanc1 & 3 & Tuzcu & 2 & Camc1 & 2 & & \\
\hline Çiftçi & 62 & Uncu & 2 & Çilingir & 15 & & \\
\hline Çoban & 4 & Yağc1 & 3 & Değirmenci & 4 & & \\
\hline \multirow{2}{*}{ Toplam } & & Müslim & & & & & 554 \\
\hline & & Gayrimüslim & & & & & 218 \\
\hline
\end{tabular}

Kumaş, dokumacılık ve boyacılıkla ilgili olan basmacılık mesleği de Hısnımansur'da gayrimüslim ahalinin icra ettiği sanatlar arasındaydı. Günlük hayatta kullanılan çeşitli eşyaların süslenmesi işiyle uğraşan basmacı esnafı bez ve kumaştan yapılmış bohça, elbise, yazma, perde, yatak takımı, nevresim ve benzeri eşyaları süslerdi. Sıklıkla kullanılan pek çok eşya basmacılar tarafından kök boya ile süslenirdi. Evlerin içi, evlerde kullanılan sandık gibi eşyalar, bazen de duvarlar basmacılar tarafından boyanarak süslenirdi. 19. yüzyıl ortalarında Adıyaman'da basmac1lık sanatına itibar edenlerin sadece gayrimüslimler olduğu kayıtlardan anlaşılmıştır. Çünkü şehirde faaliyet gösteren 4 basmacı da gayrimüslimdi.

Boyacılığın elvancılık denilen başka bir kolu daha vardır. Elvan Arapça levn yani renk kelimesinin çoğul halidir. Çeşitli renklerdeki boyaları karıştırarak nesneleri birkaç renkli, alacalı ve rengârenk boyayan sanatkâra ise elvancı denir. Vitray camlar, renkli, nakışlı ve tasvirli duvarlar elvancı ustalar tarafından nakşedilirdi. Karacaoğlan; elvan elvan nurlar doğan burçlardan, Kâtip Çelebi; rengârenk nakışlı musavver, cenk tasvirleri ve fuhuş meclislerinin tasvir edildiği duvarlardan bahsetmiştir. Rasat aletlerinde 1şı̆̆ın şiddetini hafifletmek için kullanılan elvan camlar, bitkisel boyalarla boyanmış elvan yazı kâğttları ile şişelere sarılan renkli kâğıtları 
elvancı sanatkârlar renklendirirdi. Yine elvan şekerlerine, dükkânların camlarındaki resimlere, pasta ve bisküvilere elvanc1 ustalar renklerini verirdi (Ayverdi 2011, 856-857). Elvancilar boya sanayiinde boyahanelerde de çalışırlardı. Elvancılar, boyahanelerde boya üretimi yaptıkları gibi yün, kumaş, şal, deri ve sahtiyan gibi maddeleri de istenen renklerle boyarlardı (Bozdemir 2011, 234). İncelediğimiz nüfus defterinin verilerine göre, 1835 yılında, Adıyaman'da üç elvancı ustası hünerlerini sergilemekteydi. Bunlar Ermeni (zımmî) cemaatinden İvanes, Agop ve Nerso ustalard1.

Gayrimüslimlerin en çok uğraştığı ikinci sıradaki zanaat ise köşkerlikti. Kefş-ger ve ayakkabıcı (Develioğlu 2009, 578) da denilen köşkerler deriden ayakkabı yaparlardı (Merçil 2000, 35). Köşkerlik, Hısnımansur kaza merkezinde hem Müslüman hem de gayrimüslim ahalinin en çok uğraştı̆̆ işlerden biriydi. 19. yüzyılın ilk yarısında tamamı şehir merkezinde olmak üzere 34'ü gayrimüslim ve 32'si Müslüman toplam 66 köşker esnafi bulunmaktaydı. Yalnız bunlardan bir tanesi dikici olarak defterde kayıtlıdır (Ayverdi 2011, 713). Bu esnaf yeni ayakkabıların dikiş işlerini yaptığı gibi eski ayakkabıları da tamir ederdi. Ayakkabıların ömrünün daha uzun olması için ökçelerine nalça denilen bir demir çakılırdı. Şehrin tek nalçacısı da gayrimüslimdi.

Hüner ve maharet gerektiren, ayrıca iyi gelir getiren kuyumculuk sanatı gayrimüslimlerin tekelinde olan mesleklerdendi. Kuyumcular altın ve gümüş gibi değerli madenlerden ev ve çeşitli süs eşyası imal edip satarlardı (Şemseddin Sami, 1987, 1120). İmparatorluk genelinde olduğu gibi Hısnımansur'da da kuyumculuk sanatıyla sadece gayrimüslimler uğraşmaktaydı. İncelediğimiz nüfus defterindeki verilere göre Hisnımansur'da kuyumculuk yapan 16 esnafin tamamı gayrimüslimdi.

Adıyaman şehrinde 1835 yılında gayrimüslimlerin fazlaca uğraştığı işlerden biri de çilingirlikti. Anahtar, kilit ve bunlar için gerekli ince demir parçaları yapan ve satan sanat erbabına çilingir denilmekteydi (Şemseddin Sami 1987, 515). 19. yüzyılın ilk yarısında şehir merkezinde çilingircilik yapan 15 esnaf vardı. Kuyumculukta olduğu gibi çilingircilikte de gayrimüslimler şehirde tekel kurmuşlardı. Demirden kilit ve anahtar yapan çilingirler süsleme teknikleri de kullanıyorlardı. Asit veya kimyasal maddelerle dağlama usulünü kullanarak demirden yaptıkları kilit ve anahtarları süslüyorlardı. Çilingirlerin elinde düvülerek pürüzleri giderilen demirden malzemeler kimyasal tekniklerle aşındırılıyor ve süsleniyordu (Tez 2016, 79-80).

Hısnımansur gayrimüslim ahalisinin 19. yüzyılın ilk yarısında uğraştığı işlerden biri de tüccarlıkt1. Ticaretin her zaman iyi kazanç temin edilebilen bir meslek olduğu malumdur. Şehirde bulunan 11 tüccardan 8'i gayrimüslimdi. Tüccarlar daha çok Hısnımansur'da bulunmayan kahve, kumaş, lületaşı, süs ve kullanım eşyası gibi ticaret mallarını başka yerlerden temin ederek şehre getirip satarlardı. Yine Hısnımansur ve çevresinden temin edilebilen veya sanatkârların ürettiği ticaret mallarını başka yerlere götürüp satarlardı. Kazada ticari değeri yüksek olan ürünlerden biri de tütündü. Kaza ve köylerinde üretilen tütünler şehirdeki duhancılar tarafından işlenir ve satılırdı. Tütün yetiştiren çiftçiler ve ticaretini yapan esnaf duhan resmi adı altında tütün vergisi verirlerdi (Arslan 2010).

Bakır ve demir kap ve eşyaya kalay madeni sürerek parlatma sanatı olan kalaycllık 1835 'te Adıyaman'da gayrimüslimlerin çoğunlukla uğraştı̆̆ işlerdendi. Kalay ve bakır işiyle uğraşan sanatkârlara rûger ve rûgyer de denilmekteydi (Merçil 2000, 184). Günümüzde eski itibarı kalmamışsa da, özellikle bakır kapların kullanıldığı dönemlerde kalaycılık önemli mesleklerden sayılırdı. 19. yüzyıl ortalarında, Hısnımansur'da kalaycılık işiyle geçimini sağlayan 9 esnaftan 7'si gayrimüslimdi.

19. yüzyıl ortalarında, Hısnımansur'da nalbantllk mesleği de çoğunlukla gayrimüslimler ta- 
rafından yapılmaktaydı. Atlara ve diğer tek tırnaklı hayvanlara nal takan esnafa nalbant denilir. $\mathrm{Na}$ ' l-band ve tavacı da denilen bu esnaf, aynı zamanda yaralı ve hasta hayvanların tedavisiyle de uğraşırdı. Yani bir nevi baytarlık da yapardı. 1835'te Adıyaman'da bulunan 9 nalbandın 7'si gayrimüslimdi.

Kazancılık mesleği de 19. yüzyıl ortalarında, Hısnımansur'da gayrimüslim reayanın tercih ettiği mesleklerdendi. Sözlükte kazan/kazgan; kaynatmaya has, büyük tencere (Özlü 2004, 169170), kazancı ise bakırdan kazan veya vapur kazanı yapan kimse olarak tanımlanmaktadır (Şemseddin Sami 1987, 1069; Ayverdi, 2011, 1644-1645). Düğün ve davet gibi toplantılarda çok kişiye yemek pişirmek veya kök boya imalatı, kumaş boyama ve katran kaynatma gibi farklı amaçlarla kullanılan kazanların Hısnımansur yöresinde başka ve yaygın bir kullanım alanı daha vardı ki, bu da üzümün sıkılması sonucu elde edilen şıranın kaynatılıp pekmez, pestil ve kesme yapılmasıydı. Büyük bakır kazanlar bu iş için kullanıldığından bugün dahi Adıyaman köylerinde hemen hemen her evde bakırdan kazanlar bulunur. 1835 yılında kaza merkezinde 7 ve Zırafkân aşiretinin Alut köyünde 1 olmak üzere toplam 8 kazancı bulunmaktaydı. Bu meslek de kuyumculuk ve çilingircilik gibi gayrimüslimlerin tekelindeydi.

Şehirde demircilik mesleğini icra edenlerin çoğu gayrimüslimdi. Demir işleriyle uğraşan, demirden çeşitli aletler ve eşyalar yapan esnafa demirci denilirdi. Haddâd, âhen-ger, temurcu ve teymurcu (Şemseddin Sami 1987, 59, 485, 620) da denilen demirciler ham demirden çeşitli eşyalar yapan sanatkârlardı. Adıyaman'da 19. yüzyıl ortalarında demircilikle uğraşan 7 esnaftan sadece bir tanesi Müslüman ahalidendi.

Hısnımansur'da değirmenciliği de sadece gayrimüslimler yapmaktaydı. Her türlü taneli hububatın ezilmesi, ufaltılması ve öğ̈̈tülmesi işlerini yapan işletmelere değirmen, bu işi yapanlara değirmenci denilmektedir. İnsanların temel gıdalarının çoğu taneli hububata dayandığı için değirmenlerin toplum hayatında özel bir yeri vardı. Değirmenler, daha çok hububattın öğütülmesi suretiyle un elde etmede kullanılırdı. Değirmenler su veya rüzgâr kuvvetiyle çalışırdı. Osmanlılar zamanında Anadolu'da bulunan değirmen çoğu suyla çalışan değirmenlerdi. Değirmenlerin çoğu mevsimsel şartlardan dolayı yılın sadece altı veya üç ayı çalışabilmekteydi. Yılın tamamında çalışan değirmenler de vardı. Devlet, değirmenlerin çalışma durumuna ve iş kapasitesine göre bu işletmelerden vergi alırdı.

Osmanlılar zamanında Adıyaman'da bulunan değirmenlerin çevredeki düzenli su kenarlarına inşa edildiklerini tahmin etmek güç değildir (Yiğit 2007, 106). Akarsuların kenarlarında inşa edilen değirmenler, suyun, arazinin kot farkından istifade edilerek yapılan kanallardan akıtılması sonucu değirmen taşlarının döndürülmesi suretiyle çalışırdı. Dolayısıyla değirmenlerin çoğu şehirde değil de kırsal kesimdeydi. Buna rağmen değirmencilerin çoğu şehirde oturmaktaydı. 1835 'te kentte toplam 4 adet değirmen bulunmaktaydı.

Adıyaman'da 19. yüzyıl ortalarında gayrimüslim nüfusun uğraştığı önemli sanatlar arasında kılıç̧̧llı ve tüfekçilik meslekleri de yer almaktaydı. Osmanlı ülkesinin başka şehirlerinde de görüldüğü gibi silah yapım ve tamir işleriyle gayrimüslim reaya uğraşmaktaydı. 19. yüzyılda ateşli silahlar yaygınlık kazanmış olsa da Anadolu'da kılınç kullananların sayısı da oldukça fazlaydı. Dolayısıyla kllınççı (Ayverdi 2011, 1693-1694), seyyâf (Şemseddin Sami 1987, 754) ve şimşîr-ger/şemşîr-ger) (Ayverdi 2011, 2971-2972) denilen kılınç̧̧ı esnafı şehirlerde varlığını devam ettirmekteydi. Yukarıda da belirtildiği gibi silah yapımı işleriyle gayrimüslimler meşgul olduğundan, 1835 tarihinde kentteki kılınççılık sanatı gayrimüslimlerin elindeydi. Kazada bulunan 4 kılınççı sanatkârı da gayrimüslimdi. Ateşli silahların kullanımının halk arasında yaygınlaşmasıyla gayrimüslimler tüfekçilik yapmaya başlamışlardır. Barutun patlatmasıyla içindeki kurşunu büyük bir hızla, şiddetle ve kızgın olarak uzağa atmaya yarayan ateşli silahların genel 
adı tüfeng'dir. Tüfenglerin çeşitleri vardır. Bu ateşli silahların yapımı, satışı ve tamiriyle uğraşan sanatkârlara da tüfengci denilmiştir (Şemseddin Sami 1987, 422-423; Ayverdi 2011, 3253). $\mathrm{Bu}$ silahları kullanan kimselere de tüfengci denilmekte ise de, tüfeng kullanan kimseler konumuz dışındadır. Osmanlı ülkesinde silah yapımıyla gayrimüslimlerin uğraştı̆̆ı bilinmektedir. Elimizdeki verilere göre Adıyaman'da, 19. yüzyıl ortalarında sadece gayrimüslimler tüfengcilik sanatıyla uğraşmaktaydılar. 1835 'te şehirde bu sanatı icra eden 5 sanatkâr da gayrimüslimdi.

Adıyaman'da, 19. yüzyıl ortalarında çulcu olarak geçimini sağlayan 6 zanaatkârın 4'ü gayrimüslimdi. Kıldan, kenevirden veya yünden yapılmış kaba örgülü kumaş olan çul çoğunlukla hayvanların üzerine örtü olarak konulurdu (Ayverdi 2011, 614). İnsanların ev eşyası ve sergi olarak çul kullandıkları bilinmektedir (Özlü 2004, 151). Çulcu, palan-ger ve semerci de denilen bu sanat sahiplerine kurtuncu da denilmekteydi. Çul, palan, semer ve kurtun at, merkep ve katır gibi binek hayvanlarına vurulan eyer için kullanılan bir tabirlerdir. Yine develerin üzerine atılan havut denilen palanları da çulcular ve palancılar yapardı. Çul sayesinde insanlar binek hayvanlarına bindiklerinde rahat yolculuk yapabilmekteydi. Ayrıca yük taşınması gerektiğinde palan yük ile hayvan arasında koruyucu bir tabaka işlevi görerek hayvanı zarar görmekten korumaktaydı (Toprak 2015, 92-93).

Adıyaman'da, 1835 yılında, tarakçılık mesleğiyle geçimini sağlayan üç kişi de gayrimüslim cemaatindendi. Tarakçı esnafı tarak yapıp sattığı gibi keten ve kendir elyafını taraktan geçirerek düzeltir ve temizlerlerdi (Ayverdi 2011, 3068). Yine tarakçılar iplik yapmak için yün ve pamuk gibi ham maddeleri hazırladıkları gibi hallaçların kullandığı yünleri de düzeltirlerdi.

Hısnımansur kazasında bir kısım nadir meslek erbabı da faaliyet göstermekteydi. Bu mesleklerden biri tahmisçilikti. Şehrin gayrimüslim ahalisinden sadece bir kişi tahmis işiyle uğraşmaktaydı. Tahmisçi (Ayverdi 2011, 3035) kahve çekirdeklerini tüccarlar vasıtasıyla temin ederek işledikten sonra piyasaya satard. Tahmisçi, kahve çekirdeklerini ateşte kavurarak döver veya kahve değirmeninde çektikten sonra satışa sunardı. Kuru kahveci de denilen şehrin tek tahmisçisi hem Adıyaman halkının kahve ihtiyacını karşılar, hem de şehirde bulunan on kahvecinin tükettiği kahveyi hazırlardı.

Adıyaman'da 1835 senesinde ölçü ve tartı işleriyle uğraşan iki ölçekçi esnafı bulunmaktaydı. Ölçek kelimesi sözlükte; hububat ölçmeye mahsus ölçü, şinik ve kilenin dörtte biri olarak tanımlanmıştır. Bir ölçek iki kutuya bölünmüş olup dört okkadan ibarettir (Şemseddin Sami 1987, 219; Ayverdi 2011, 2452). Bir şeyi ölmek için temel birim sayılan ölçekle tahıl ve benzeri maddeleri ölçen kişiye de öçekçi denilmekteydi. Çarşı ve pazarda tahıl dışında ölçülmesi ve tartılması gereken ticaret eşyasının miktarı da ölçekçiler tarafından belirlenirdi. Ölçü ve tartı işiyle uğraşan iki esnaf da gayrimüslimdi. Pazarda tartı işiyle ilgilenen kişiye kantarcı dense de defterde kayıtlı kantarcı yoktur. Ölçü ve tartıyla ilgilenen iki esnafın da ölçekçi olarak kaydedildiği kanaatindeyiz. Oysa 1846 tarihinde Besni'de Ermeni bir kantarcının olduğu bilinmektedir (Toprak 2015, 1679). Günümüzde dahi Besni pazar yerinde bir kantarcı hizmet vermektedir.

İlk nüfus sayımının yapıldığı 1835 yılında Adıyaman'da yaşayan gayrimüslimlerden iki kişi camcılık yaparak geçimini sağlamaktaydı. Şehrin iki ekmekçisi de gayrimüslimdi. Mest ile birlikte giyilen bir nevi ökçesiz ayakkabı üreten iki pabuççu (Özlü 2004, 144) da aynı cemaattendi. Kazada bulunan iki gayrimüslim külhancı da kazanın tek hamamcısı olan bir Müslümanın yanında çalışmaktaydı. Şehirde bulunan iki gayrimüslim lüleci tütün içilen çubuklar ile nargilede kullanılan lüle denilen aletleri yaparlardı. Lüleciler ayrıca topraktan yazı hokkası, fincan, kahve şeker kutusu ve tütün kâsesi benzeri eşyaları imal ederlerdi (Pakalın 1971, 372). Kazada iki gayrimüslim zeylci sanatlarını icra etmekteydi. Zeylciler daha önce yazılmış yazı veya 
kitaplara ekleme yapan veya eski eserlerin devamı olarak ek ve ilave yazan yazı ustalarıydı. Yine sırtıyla eşya taşıyarak para kazanan bir hamal, kürk temin ederek satan bir kürkçü ile hastaları tedavi ederek geçimini sağlayan bir hekim de aynı cemaattendi.

Şehirde icra edilen nadir mesleklerden biri makrama, mahrama veya mehreme denilen zanaattı (Özlü 2004, 192-193). Hristiyan cemaatinden olan şehirdeki tek makramacı kabaca iplik ve sicimleri geometrik biçimlerde desenler oluşturacak şekilde düğümleyerek danteller yapar, bu dantelleri el havlularının etrafına dikerdi. Makrama denilen kenarı işlemeli peşkir, destmal, havlu ve el bezlerini yapan makramacı bunları satarak geçimini sağlardı. Bazı bölgelerde kadınların başlarına örttükleri geniş ve nakışlı örtülere de makrama/makrame denilirdi (Ayverdi 2011, 1944-1945). Adıyaman yöresinde de makrama denilen bu örtüler kadınlar tarafindan kullanılırdı.

1835 yılında Hısnımansur'da mahsaracılık yaparak geçimini saplayan bir sanatkâr bulunmaktaydı. Gayrimüslim cemaatinden olan bu mahsaracı (masaracı), bağbozumu mevsiminde mesleğini icra etme imkânı bulurdu. Çokça üzümün yetiştirildiği bölgede ağustos ayı sonundan itibaren bağbozumu mevsimi başlardı. Üzümlerin toplandıktan sonra suyunun posasından ayrılması için sıkılması işleminden sonra pekmez yapılması için büyük kazanlarda kaynatılması gerekirdi. İşte mahsaracı sanatını bu aşamalarda gösterirdi. Şire pişirmede kullanılan mahsara kazanında üzüm suyunu belli bir kıvamda koyulaştırarak pişirdikten sonra üç ile altı gün mayalamaya bırakır, daha sonra önceki yıldan kalan pekmezle karıştırırdı. Bu sürede içindeki şekerin kristalleşmesiyle pekmez altın sarısı bir renk alırdı. Pekmezden pestil, sucuk, dilme, kesme, kırma gibi çeşitli yiyecekler yapılırdı (Özlü 2004, 244).

\section{Nüfus Yapısı}

19. yüzyılın ilk yarısında Hısnımansur'da yaşayan gayrimüslim nüfus oldukça dinamik bir yapıya sahipti. İyi gelir getiren sanat, iş ve mesleklerle uğraşarak varlıklarını devam ettirmekteydiler. İncelediğimiz nüfus defterinin düzenlendiği tarihte imparatorluk genelinde henüz gayrimüslimler askerlik hizmetiyle yükümlü tutulmadıklarından, gayrimüslim erkekler askere alınmamaktaydı. Askere gitmedikleri için erkek nüfusta eksilme olmuyordu. Gayrimüslim erkekler genç yaştan itibaren sanat ve mesleklerine başlamakta, iş hayatları askere alınma gibi nedenlerle kesintiye uğramadığından mesleklerinde ustalaşmakta ve ilerleme imkânı bulmaktaydılar. Dolayısıyla kesintisiz devam eden meslek hayatlarında başarılı olma olanağına sahiptiler.

1835 yılında Adıyaman' da yaşayan gayrimüslim nüfusun yaklaşık üçte biri on yaşın altında bulunan fertlerden oluşmaktaydı. Çalışmamıza kaynaklık eden nüfus defterinde kayıtlı gayrimüslim erkek nüfus üzerinden hareket edersek; toplam 749 kişiden 258 'i 0 ile 10 yaşları arasinda bulunmaktaydı. Yine 134 kişi 11 ile 20, 141 kişi 21 ile 30, 94 kişi 31 ile 40 ve 49 kişi 41ile 50 yaşları arasındaydı. Elli yaşından büyük olanların sayısı ise 73 'tü. Buna göre tahmini olarak gayrimüslim nüfusun yüzde 34'ü 0 ile 10 , yüzde 18 'i 11 ile 20 , yüzde 19 'u 21 ile 30 , yüzde 13'ü 31 ile 40 ve yüzde 7'si 41 ile 50 yaşları arasında bulunmaktaydı. Daha geniş bir skalada değerlendirdiğimiz yaşlı nüfus ise toplam nüfusa oranla azınlıktaydı. Buna göre şehirde yaşayan gayrimüslim erkeklerin sadece 73 'ü 51 ile 90 yaşları arasında bulunmaktaydı. Bu sayı tahmini olarak nüfusun yüzde 10'una denk gelmekteydi.

Yaşlı olarak nitelendirdiğimiz grubun içerisinde 80 yaşından büyük 11 kişi bulunmaktaydı. İncelediğimiz nüfus defterinde herhangi bir özrü ve hastalığı bulunanlar için ayrıca ismin üzerine notlar düşülmüştür. 80 yaşından büyük yaşlı grup içerisinde sadece bir kişi için hasta bilgisi not edilmiştir. Bu veri Hısnımansur gayrimüslimlerinin rahat, sağlıklı ve uzun bir ömür sürdürdüklerini göstermektedir.

İncelediğimiz nüfus defterinin verilerine göre 19. yüzyılın ilk yarısında Hısnımansur'da 
yaşayan gayrimüslim cemaatinin fertleri oldukça sağlıklı bir hayat sürmekteydiler. Kaza sınırlarında yaşayan yaklaşık 1.238 kişiden sadece 31 kişide çeşitli uzuv eksikliği veya özrü bulunmaktaydı. 1835 yılı nüfus kayıtlarına göre Adıyaman'da 6 kişi amâ yani kör, 12 kişi yek-çeşm ve 3 kşi aver yani tek gözlüydü. Bu verilere göre şehirde yaşayan gayrimüslimlerden 21 kişide görme özrü bulunmaktaydı. Kaynağımız olan defterin kayıtlarına göre, aynı tarihte, kaza dâhilinde göz özrü bulunan fertlerin sayısı 147 'dir. Şehir nüfusunun yaklaşık beşte birini oluşturan gayrimüslim ahalinden göz özrü olanların şehirdeki tüm göz özrü olanlarına oranı ise yüzde 14 civarındadır.

Gayrimüslim cemaatinden üç kişi ise alil yani sürekli harap, bitkin ve hastayd. Alil olanlarda ikisi aynı zamanda kör, biri de mecnundu. Sözlük anlamına göre mecnun kişiler cinnet geçiren, çıldıran, aklı başından giden ve deliren kişilerdir (Ayverdi 2011, 1998). Elimizdeki verilere göre alil olan mecnun dışında şehirde bir gayrimüslim mecnun daha vardı. Yine aynı tarihte gayrimüslimlerden üç çolak yani tek kolu sakat, dört topal ve bir felçli fert bulunmaktaydi.

\section{Sonuc}

Osmanlı Devleti, yeni kurduğu Nizamiye Ordusunun asker ve finans ihtiyacını karşılayacak insan kaynağını tespit etmek amaciyla 1831'den itibaren modern anlamda nüfus sayımları yapmaya başladı. Bu bağlamda, 1835 yılında, Adıyaman'da yapılmış olan ilk nüfus sayımı verilerine göre şehrin demografik durumunu tespit etme imkânı bulduk. Bu çalışmada sadece gayrimüslim ahalinin verileri incelenmiş ve şehrin yaklaşık beşte birlik nüfusunu oluşturan gayrimüslim cemaatinin oldukça genç ve dinamik nüfus yapısına sahip olduğu ortaya çıkmıştır.

Tamamına yakını şehir merkezinde yaşayan gayrimüslim nüfusun şehrin ekonomik yapısında kilit bir noktada bulunduğu tespit edilmiştir. Şehir nüfusunun yaklaşık beşte birini oluşturan cemaat mensupları, şehirde icra edilen iş ve meslek kollarının beşte ikisini ellerinde tutmaktaydılar. Hısnımansur'da Müslümanlar daha çok bedensel güç ve kuvvet gerektiren, zor ve nispeten az gelir getiren rençberlik, çiftçilik ve dericilik gibi işlerle uğraşırken gayrimüslimler hüner, maharet ve ustalık gerektiren kuyumculuk, boyacılık ve çilingirlik meslekleriyle meşgul olmuşlardır.

Gayrimüslimlerin iş ve mesleklerinde ilerleme imkânı bulmalarının askere alınmamalarıyla yakın bir ilişkisi vardır. Uzun süre orduda bulunan Müslüman erkeklerin zanaat ve meslek edinmeleri oldukça zor iken gayrimüslimler çocukluktan itibaren sanatlarında ustalaşmakta idiler. Dolayısıyla şehrin gayrimüslim nüfusu, nüfusun Müslüman kesimine göre nispeten rahat ve müreffeh bir hayat sürme imkânına sahipti. 


\section{KAYNAKC A}

Ahmed Lütfi Efendi. (1999). Vak'anüvis Ahmed ûtfí Efendi Tarihi. Cilt II-III. İstanbul 1999. Yeni yaziya akt. Yücel Demirel \& Tamer Erdoğan. İstanbul 1999.

Arslan R. (2010). “XIX. Yüzy1lda Adıyman'da Sosyo-Ekonomik Yap1”. Dumlupınar Üniversitesi Sosyal Bilimler Dergisi 26 (2010) 288-301.

Ayverdi İ. (2011). Misalli Büyük Türkçe Sözlük. Cilt. I-III. İstanbul 2011.

Barkan Ö. L. (1953). “Tarihi Demografi Araştırmaları ve Osmanlı Tarihi”. Türkiyat Mecmuası X (1953) 1-25.

BOA Başbakanlık Osmanlı Arşivi. NFS.d. 2697; 2699; TT, 266.

Bozdemir M. (2011). Osmanlıdan Cumhuriyete Endüstriyel Mirasımız. İstanbul 2011.

Çadırcı M. (2013). Tanzimat Döneminde Anadolu Kentlerinin Sosyal ve Ekonomik Yapısı. Ankara 2013.

Çimen A. (2012). "Sayım, Kayıt Düzeni ve Teşkilatlanma Açısından Osmanlıda Nüfus Hizmetleri”. Gazi Üniversitesi İktisadi ve İdari Bilimler Fakültesi Dergisi 14/3 (2012) 183-216.

Demirci S. \& Kartal, K. (2014). "Osmanlı Nüfus Defterlerinin Tarih Yazımındaki Yeri: 1835 Tarihli Trabzon Vilayeti Maçıka/Maçka Kazâsı Müslim Nüfus Defteri”. History Studies International Journal of Hiistory 6/3 (2014) 119-145.

Develioğlu F. (2009). Osmanlıca-Türkçe Ansiklopedik Lûgat. Ankara 2009.

Hüseyin Remzi. (1306). Illaveli Müntabahât-ı Lugât-i Osmaniyye. Cilt II. Dersaadet 1306.

Karal E. Z. (1997). Osmanlı Imparatorluğunda İlk Nüfus Sayımı 1831. Ankara 1997.

Karpat H. K. (2010) Osmanlı Nüfusu. İstanbul 2010.

Kenanoğlu M. M. (2004). Osmanlı Millet Sistemi-Mit ve Gerçek. İstanbul 2004.

Kütükoğlu M. S. (2013). Osmanlı Belgelerinin Dili. Ankara 2013.

Merçil E. (2000). Türkiye Selçukluları'nda Meslekler. Ankara 2000.

Özlü Z. (2004). XVIII. Yüzyllın İkinci Yarısında Gaziantep. Gaziantep 2004.

Pakalın M. Z. (1971). Osmanlı Tarih Deyimleri ve Terimleri Sözlüğü. Cilt. II. İstanbul 1971.

Redhouse S. J. (1999). Redhouse Türkçe/Osmanlıca-İngilizce Sözlük. İstanbul 1999.

Taşkın Ü. (2011). Osmanlı İdaresinde Safed (1516-1600). Elazığ 2011.

Taşkın Ü. (2013). "XVI. Yüzyılda Aclun Şehri ve Kasabalarının Nüfusu”. Turkish Studies 8/7 (2013) 645-654.

Taştemir M. (1999). XVI. Yüzyllda Adryaman. Ankara 1999.

Tez Z. (2016) Meslekler Tarihi. İstanbul 2016.

Toprak S. V. (2015). Besni-1846 Tarihli Bir Kefalet Defterine Göre Nüfus ve Sosyal Hayat. Adıyaman 2015.

Ünal M. A. (2011). Osmanlı Deyimler Sözlüğü. İstanbul 2011.

Ürek M. (15.03.2016). Görüşme. Adlyaman Süryani Kadim Metropoliti.

Yiğit A. (2007). "XIV-XVI. Yüzyıllarda Menteşe Livasında Değirmenler”. MÜ Sosyal Bilimler Enstitüsü Dergisi (ILKE) 18/Bahar (2007) 97-155. 
3 है

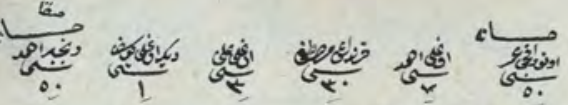

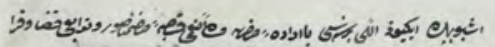

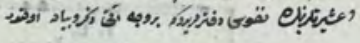

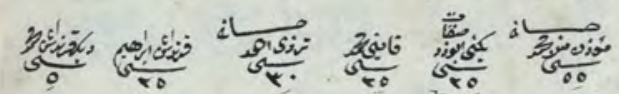

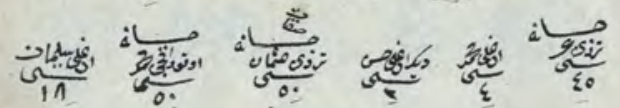

宊

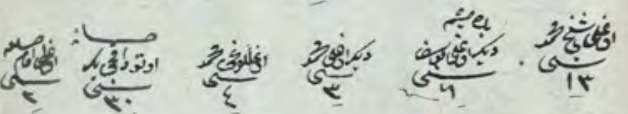

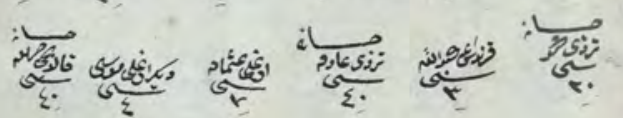

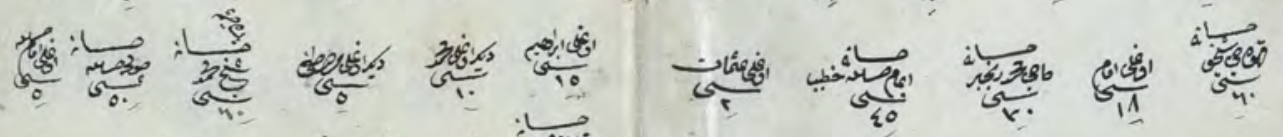

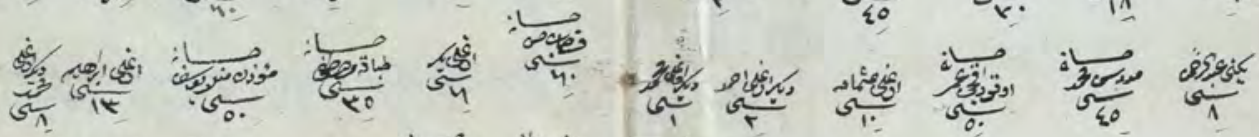

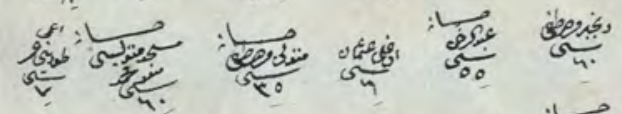

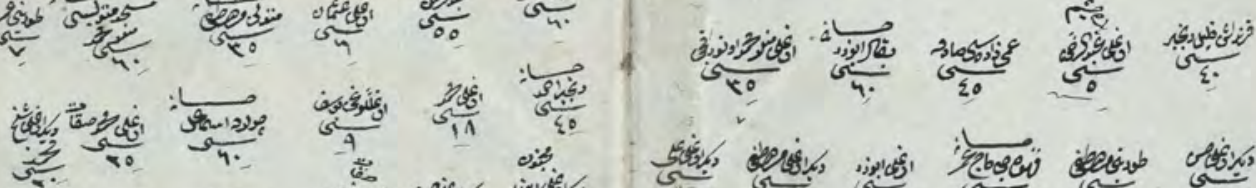

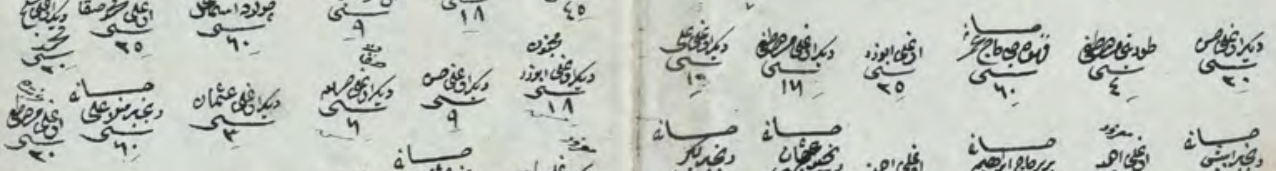

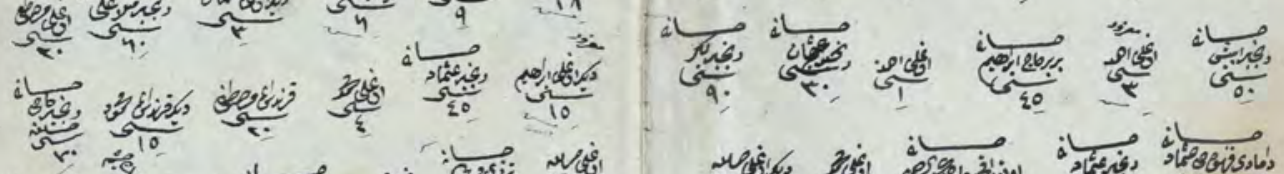
宊

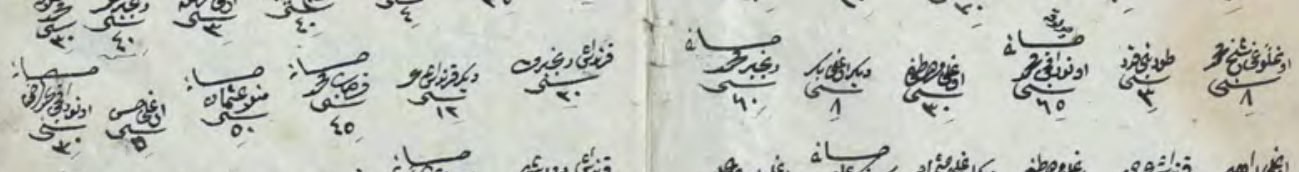
䒠

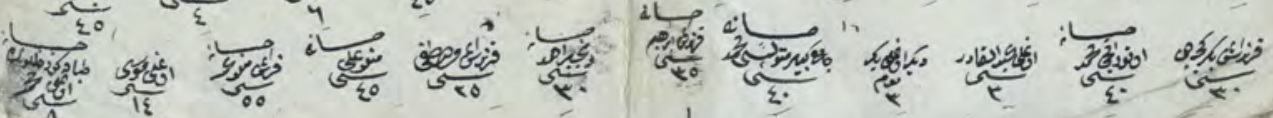

Fig. 1. Hicri 1251 Tarihli Hısnımansur Nüfus Defteri’nin başlangıç sayfaları. 


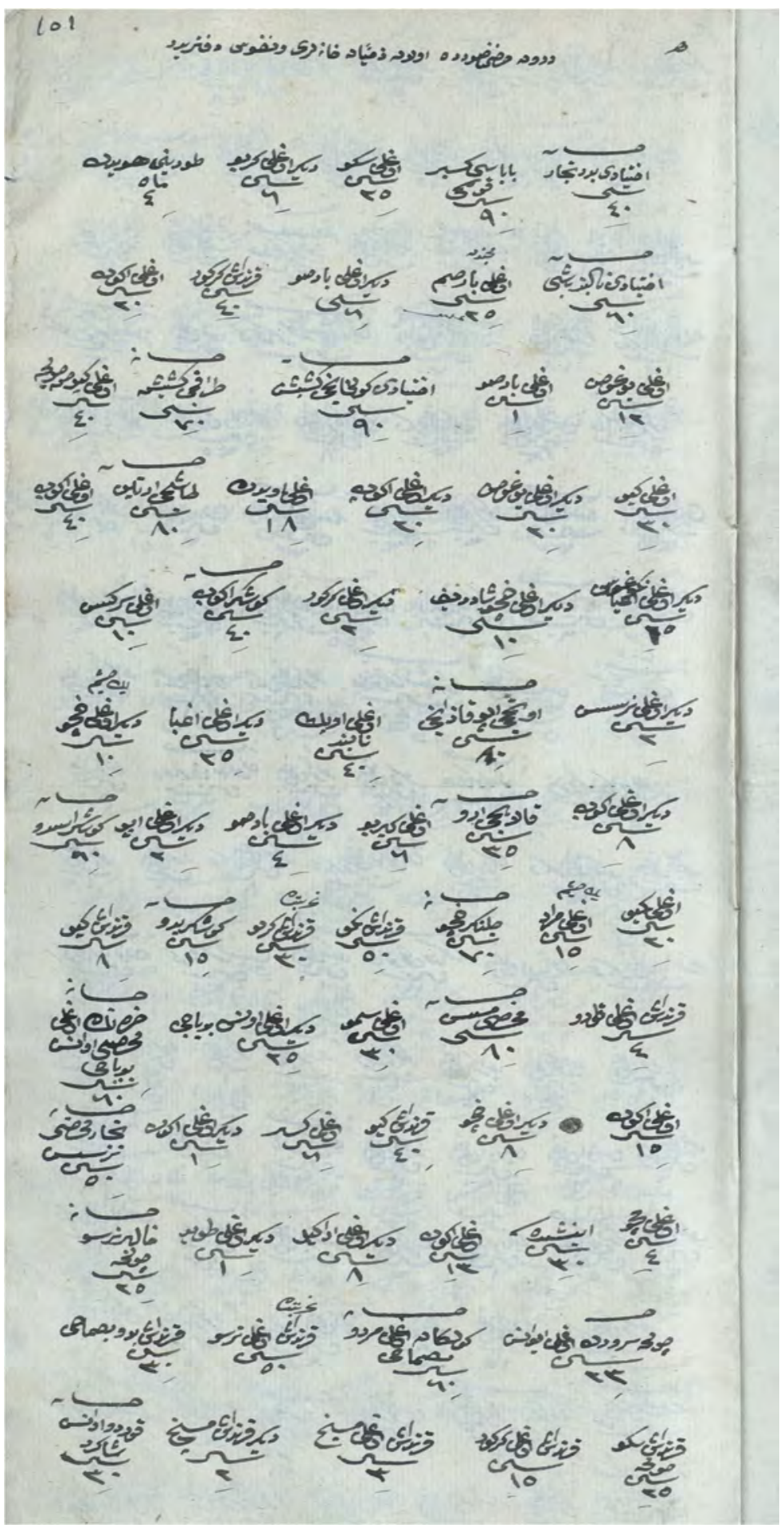

Fig. 2. Hicri 1251 Tarihli Hısnımansur Nüfus Defteri'nde Gayrimüslim hanelerinin kaydedildiği ilk sayfa. 


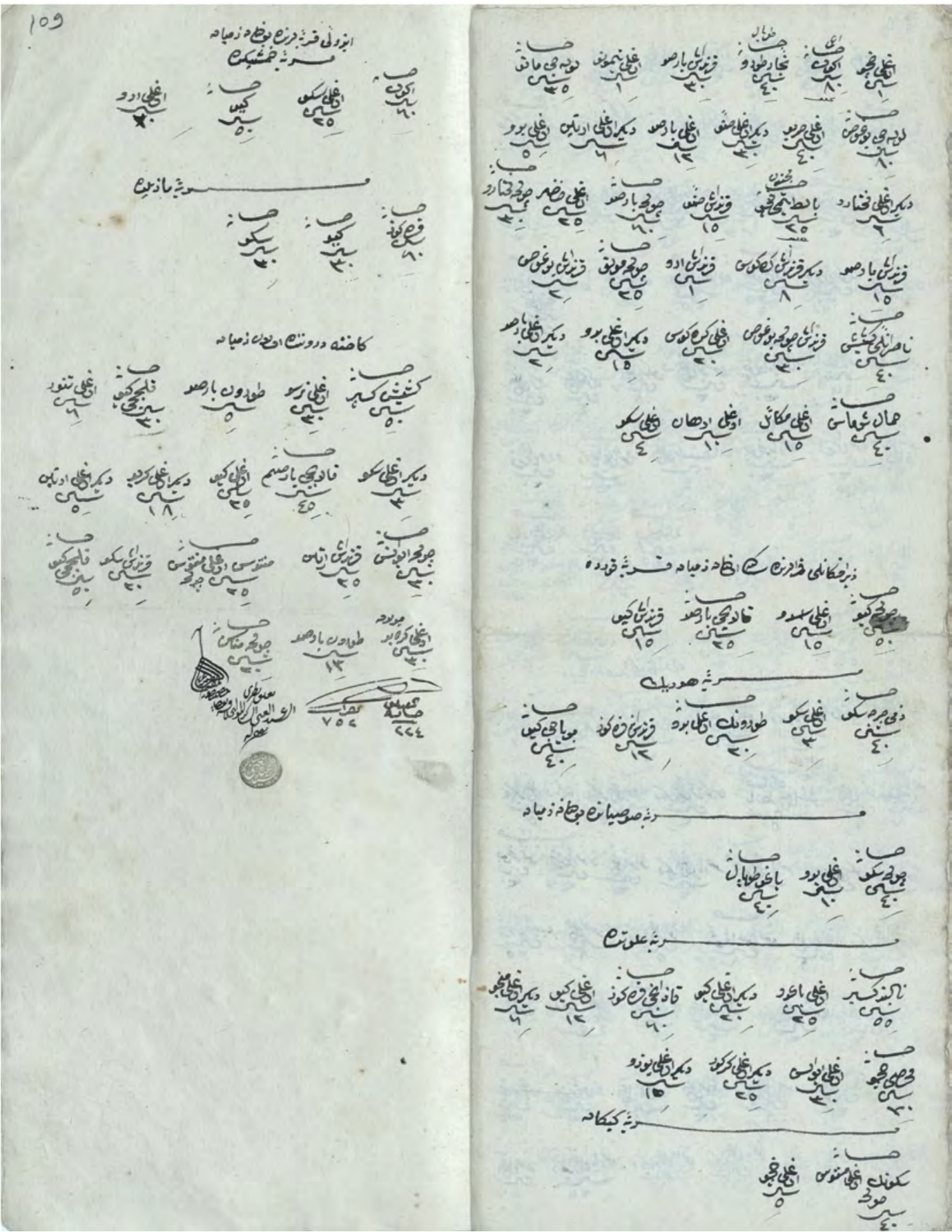

Fig. 3. Hicri 1251 Tarihli Hısnımansur Nüfus Defteri’nin son sayfası. Gayrimüslim hanelerinin kayıtlı olduğu son sayfada Hısnımansur Kadı Naibi Es-Seyyid Abdülgani Şâkir Efendi'nin imza ve mührü mevcuttur.

Figürler BAŞBAKANLIK OSMANLI ARŞIVİ'nden alınmıştır. 